\section{The Interplay of Space, Place and Identity: Transforming Our Learning Experiences in an Outdoor Setting}

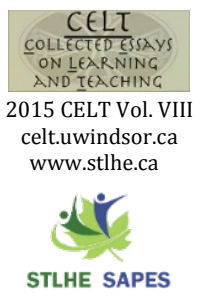

\author{
Alice L.E.V. Cassidy \\ University of British Columbia
}

W. Alan Wright

University of Windsor
William B. Strean

University of Alberta

Gavan P.L. Watson

Western University

In this paper, we use a day-long professional development workshop for higher education faculty conducted in an outdoor setting as the starting point for an examination of the value of such activities. We explore the potential benefits, in terms of learning and holistic well-being, of educational activities designed to provide participants with sessions either in the natural environment or the built (urban) environment beyond the four walls of the traditional classroom. Drawing on the literature of 'place-based learning', the well-established traditions of some conference organizations, the emerging trend to mount such pre-conference workshops in the Society for Teaching and Learning in Higher Education (STLHE: Canada) and the feedback of past participants, we explore the nature of these experiences and the various outcomes, grappling with the challenge of identifying tangible 'takeaways' at the individual and community levels. We conclude with directions for further analysis of the role of this type of session in terms of conference pedagogy and means of measuring impact on the well-being, outlook, and practices of instructors in higher education.

\title{
Orientation
}

$M_{\text {transformations underway in higher education }}^{\text {uch has been written about major }}$ (Barr \& Tagg, 1995; Brookfield, 2000; Cranton, 1994). Articles and books are replete with studies, analysis, and commentaries concerning the failure of higher education, the crisis of financing universities, the crippling burden of student debt, and educational technologies transforming the learning experience to the point that the very existence of traditional face-toface classroom learning is said to be under threat.
Some examples describe a movement from someone in front of a large computer-generated image in a traditional lecture hall to that of an asynchronous learning experience whereby a lone student is face-toface with a computer screen. Yet, despite the transformations higher education is undergoing, common to both these experiences is a certain sense of place: the Internet or the lecture hall all have a feeling of 'somewhere' for those participating. 
Although educational developers are among the first to acknowledge that experiential learning à la Kolb (1984) and practical internships help provide invaluable learning experiences for post-secondary students, conference pedagogy tends to be largely stuck in the age of historic presentation followed by question and answer, coupled in some instances with interactive conversation and small group activities. But even the more adventurous of conference sessions are, on the whole a homogeneous experience: conducted in traditional campus classroom settings, with the insistence on the provision of movable seating often the most 'radical' departure from the rows and rows of eager learners which is the traditional norm. Leaving a conference with any sense of the place often happens in spite of the formal learning.

For several years a number of university professors and educational developers have conducted day-long workshops in outdoor settings on the preconference day of the Society for Teaching and Learning in Higher Education (STLHE; see Table 1).

Table 1

SUmmary of STLHE outdoor pre-conference sessions led by some or all of the authors

\begin{tabular}{|c|c|c|c|}
\hline Year & Host city & $\begin{array}{l}\text { Paddling } \\
\text { location }\end{array}$ & Conference theme \\
\hline 2005 & $\begin{array}{l}\text { Charlottetown, } \\
\text { Prince Edward } \\
\text { Island }\end{array}$ & North Rustico & $\begin{array}{l}\text { A Fine Balance: The Student Experience of } \\
\text { Learning }\end{array}$ \\
\hline 2006 & $\begin{array}{l}\text { Toronto, } \\
\text { Ontario }\end{array}$ & $\begin{array}{l}\text { Harbourfront } \\
\text { and Toronto } \\
\text { Island }\end{array}$ & Knowledge and Its Communities \\
\hline 2007 & $\begin{array}{l}\text { Edmonton, } \\
\text { Alberta }\end{array}$ & $\begin{array}{l}\text { Fort } \\
\text { Edmonton } \\
\text { Park } \\
\end{array}$ & Evolving Scholarship \\
\hline 2008 & $\begin{array}{l}\text { Fredericton, } \\
\text { New } \\
\text { Brunswick }\end{array}$ & St. John River & A World of Learning \\
\hline 2013 & $\begin{array}{lr}\text { Cape } & \text { Breton } \\
\text { Island, } & \text { Nova } \\
\text { Scotia } & \\
\end{array}$ & $\begin{array}{l}\text { Louisburg Bay } \\
\text { and Fortress }\end{array}$ & Learning to Live; Learning for Life \\
\hline 2014 & $\begin{array}{l}\text { Kingston, } \\
\text { Ontario }\end{array}$ & $\begin{array}{l}\text { St. Lawrence } \\
\text { River and } \\
\text { Cedar Island }\end{array}$ & Transforming our Learning Experiences \\
\hline
\end{tabular}

Participants come from across Canada (Wright, Cassidy, \& Monette, 2013) and occasionally further afield. For some, "it is one of the reasons I decided to attend STLHE”, noted by a participant.

In one past workshop, the facilitators focused on paddling and navigating a canoe as a metaphor for teaching, allowing instructors "the opportunity to explore the multiple meanings of metaphors in situ and with colleagues in a cross-disciplinary setting" (Wright, Monette, \& Hamilton, 2010, p. 75). All of the outdoor workshops mentioned here may be seen as a reminder to participants of the essentially contextual nature of our teaching practice. In every case the facilitators collected written feedback from participants, and in every case the 'satisfaction index', our data source for this paper, was very high. 
Comments such as:

"This place fosters a way of knowing Unlike the (typical) conference space It is new, yet feels like home."

"Water is good for the soul."

from participants of the Transforming our Learning Experiences: Paradigms and Paddling Pedagogies all-day pre-conference workshop in Kingston, Ontario (June $\left.17^{\text {th }}, 2014\right)$ tell us, as the facilitators, that this kind of conference session is valuable in a variety of ways and for a variety of reasons.

In this paper, we set participant responses to the workshop experience in the tradition of 'placebased', experiential, holistic, and community learning experiences with a view to going beyond the 'satisfaction index' and defining more a more tangible rationale for making such sessions an integral part of progressive conference pedagogy.

Our most recent pre-conference workshop allowed us to explore Cedar Island in the St. Lawrence Islands National Park near Kingston, Ontario. The framework of place and place-based learning informed, in part, the design of the workshop. Place, as a concept, is distinctly interdisciplinary with biophysical, sociocultural, economic, political and psychological aspects. The field of place-based learning considers, in part, "how people connect with places and how those connections influence...[our] engagement with the environment" (Ardoin, Schuh, $\&$ Gould, 2012, p. 584). As we believe that education, regardless of setting, ought to have "some direct bearing on the well-being of the social and ecological places people actually inhabit" (Gruenewald, 2003, p. 3 ) it was our goal, in part, to foreground the land as pedagogical partner.

As facilitators, we acknowledged the importance of an experience that fostered building connections between ourselves and others, including the land and water surrounding Kingston. Participants agreed, with comments such as "interconnectedness with each other, the water, the land" and "an opportunity to make friends and feel welcome." While we were only travelers on and upon the lake and landscape, reflecting on the meaning we took from Cedar Island was meant to be a metaphor for us to consider our engagement with our own environments of learning in higher education. In turn, we asked participants to reflect on the conference theme of transformation, considering the role, if any, of an environment, such as the one travelled through, as a catalyst for their own transformative learning (Walter, 2011). We acknowledge that experiencing something new or novel could be a factor in the favourable responses from the participants, but the importance of the role of first-hand experience outdoors cannot be discounted in fostering personal change (see, for example Revell, Duncan, \& Cooper, 2014, for details of participants' perspectives towards the impact of nature in fostering therapeutic change).

Meeting in the morning, participants, organized by skill level, departed in canoes and kayaks to Cedar Island. Upon arrival, we broke into smaller groups and based on learner interests, explored various facets of the natural St. Lawrence environment and prepared a communal lunch. We aimed to make the most of the outdoor environment, creating conditions designed to offer memorable individual, small group, and whole group experiences for twenty-five STLHE Conference participants. In the words of Baldwin et al. (2013): "the common thread running through all of our teaching is that place matters because it encourages new ways of questioning and being in the world." (p. 2) It was a moderately challenging day involving physical activity and experiential learning (Kolb, 1984) consisting of active experimentation in place, reflective observation, recording impressions and drawing on personal experiences to conceptualize a sense of these activities in the context of our own personal pedagogies.

\section{The Value of Nature-based and Whole-Body Learning}

"Our goal should be to live life in radical amazement, to look at the world in a way that takes nothing for granted. Everything is phenomenal; everything is incredible; to be spiritual is to be constantly amazed." 
(Rabbi Abraham Joshua Heschel in Louv, 2012, p. 72)

We (as academics) and our students are facing chronic cognitive overload in proportions never before contemplated. Although the notion of cognitive fatigue was explored in early psychology by the likes of William James and Edward Thorndike, it is unlikely that they could have imagined the volume of stimuli that would be hitting us all on a nearly constant basis. They did understand, however, that as distractions increase, the amount of effort needed to stay on task increases, along with the rate of mental fatigue (Selhub \& Logan, 2012).

Part of our goal in creating a paddling workshop was to provide experiential learning that would raise awareness about our 'new normal' operating states in higher education. In addition to our sense of overload, there is another element in the brain fitness discourse that is quite important and yet overlooked. Only infrequently do considerations of brain function consider what it really costs to have (cognitive) inhibition fatigue. Inhibition is an essential brain regulator, with executive function keeping brain energy away from distractions and focusing attention where needed. Given all the distractions we live with, our filters are burdened, trying to save us from information overload. Think about yourself surfing the Internet and the effort it takes to stay diverted from all the little bells and whistles dancing around the text you want to read.

Nature provides stress relief and ways to heal our brains from the bombardment to which we subject them so regularly. Kaplan (1977) suggested that natural environments are fascinating so they keep involuntary attention without needing to expend the brain's energy that would otherwise create cognitive fatigue. Nature experiences can encourage a sense of cognitive clarity and remove confusion. This kind of mental focus has done our species well for millions of years in the natural environment. As Kaplan (1977) posited, being mentally fatigued and distracted would have been deadly on the African savanna. The fascination provided by natural environments safeguarded our survival by fostering mental clarity without requiring lots of energy. All of the 'infotoxins' (information of dubious quality) entice us disguised as interest, but because they are not important or fascinating, they tend to suck away our energy.

The original work on the benefits of nature on cognition address the idea of attention restoration therapy and later Kaplan (1995) proposed four major components: a mental break or 'being away'; fascination with the natural world; the vastness of nature's expanse; and the ease with which natural environments are compatible with a mental respite.

Recent findings have broadly supported Kaplan's hypothesis. Shin and colleagues (2011) in Seoul, South Korea, a city privileged enough to have a huge urban national park system, evaluated the cognitive effects of a walk through a pine forest versus downtown streets. Participants, before and after 50minute walks, completed pre- and post-cognitive and mood assessments. On another day, the groups were switched: the urban walkers ventured into the forest and vice versa. Results revealed the expected increases in mood among the forest walkers compared with the urban walkers, and they also showed that only after the forest walks did participants' cognition improve. Nisbet and Zelenski (2011) echo similar findings in their work, describing how outdoor walks in 'nearby nature' facilitated a sense of connection with the natural world and increased happiness. Participants in another study reported that immersion in natural environments increased their value of intrinsic aspirations, or goals that satisfy basic psychological needs (Weinstein, Przbylski, \& Ryan, 2009).

Mental fatigue can also impair physical performance in healthy adults. Participants were placed in two conditions prior to jumping on stationary bikes (Marcora, Staiano, \& Manning, 2009). In one they faced cognitively demanding computer tests, the controls just watched an emotionally neutral documentary on the Orient Express or Ferrari (the nature content of these videos was not reported). The differences between the groups on the cycle-to-exhaustion test were remarkable: the mentally fatigued group gave up quickly, having 
reached a maximal level of perceived exertion much faster. In short, a mentally fatigued mind causes a tired body. This helps to explain why it is so hard for many overworked people to get out and exercise.

Adult memory performance can be disrupted by a short period of increased levels of the stress hormone cortisol (e.g. Lupien et al., 2005), and just low-level elevation of pro-inflammatory immune chemicals (cytokines) weakens verbal and nonverbal memory (Selhub \& Logan, 2012). Nature can decrease stress hormones and stabilize inflammation. Accordingly, nature can be of great value to cognitive health. It seems that nature can enhance cognition by mechanisms that involve mood and stress, and also particularly through reducing demands on voluntary attention and inhibition. Notwithstanding this desirable, low-cost intervention, in a world packed with cognitive demands, many are missing the restorative power of nature and reaching instead for another Red Bull.

Other studies (e.g., Matsuoka, 2010) show that exposure to nature views enhance academic performance. Activities conducted in green space can reduce the symptoms of ADHD (e.g., Taylor \& Kuo, 2009). Godbey (2009) presents a wonderful literature review with many more examples. Time in nature is clearly a means of enhancing mental outlook, reducing stress, increasing well-being, and life satisfaction. We found no evidence to the contrary in the literature. We note that some beginner paddlers may have experienced some stress as they started out, but, upon successful completion of the day's adventure, espoused feelings of satisfaction.

Participants' comments show the transformative nature they experienced: "all our senses are made aware of our environment"... "the creation of a context in which this kind of reflection becomes possible"... "I was part of a learning community today"... "Time just to be"... "a clear sense of the natural context in which the Conference is taking place"... "A day of contemplation and metacognition"... "overcoming obstacles and challenges"... "a great day of reflection and paddling"... "I know a new place today only because I paddled there"... "the interplay of space, place, and identity"... "loved matching a topic area with a physical activity."

\section{Practical examples}

A volume by Wattchow \& Brown (2011) is dedicated to the Pedagogy of Place, with a special focus on outdoor education. Nesbit \& Mayer (2010) pointed to the affective learning gains, especially student beliefs about the course topic, as a result of field trips. In your course or program, you may or may not be able to take students on an actual field trip. But there are many ways to bring the inside out and the outside in.

Table 2

Examples of activities connecting the outside with the inside classroom

\begin{tabular}{|l|l|}
\hline \multicolumn{1}{|c|}{ I. Outside } & \multicolumn{1}{c|}{ II. Inside } \\
\hline $\begin{array}{l}\text { a) Take students on a } \\
\text { field trip during regular } \\
\text { class }\end{array}$ & $\begin{array}{l}\text { a) Show something of } \\
\text { the outside world } \\
\text { during your indoor class }\end{array}$ \\
\hline $\begin{array}{l}\text { b) Take students just } \\
\text { outside the front door } \\
\text { for 15 minutes of } \\
\text { regular class }\end{array}$ & $\begin{array}{l}\text { b) Bring an object from } \\
\text { outside into class }\end{array}$ \\
\hline $\begin{array}{l}\text { c) Give an assignment } \\
\text { that must be completed } \\
\text { outside }\end{array}$ & $\begin{array}{l}\text { c) Encourage } \\
\text { connections between } \\
\text { outside and inside }\end{array}$ \\
\hline
\end{tabular}

In the Outside column of Table 2, if the field trip (Ia) is done during regular class time, of course the longer your class runs, the better. One of us (Cassidy), who taught a 3rd interdisciplinary science course taking place once a week for 3 hours, took students by bus to a local bog, and lined up a volunteer expert to explain its relevance. This of course was a special situation. Is your class 50 minutes long? How about, as in Ib, taking your students outside, even for a few minutes, can go a long way. Whatever your discipline, think of what you can show students or ask them to make note of. In Ic, the assignment Cassidy gave her students was a photo assignment (take a picture and be prepared to show it in next class and explain its relevance to the course topic, which in this case was human connections to ecology.) What about having students conduct a short inventory or make a list, in 
their assignment, of all the ways things they note outside connect to the topic of your course?

Turning to the Inside column of Table 2, there is always a way to show students something in class that is based on the 'outside', be it the natural world, or more broadly, outside the classroom (such as showing a video or website or assigning a reading).

In the interdisciplinary science course, with its focus on making good field notes and thinking critically, Cassidy 'brought in' a unique item to start each class, such as a Douglas Fir cone, imitating an owl vocalization, or showing an image where it was hard to tell the scale. Students posed questions that might help them determine what the item was, thus honing their scientific method skills. If you asked your students to make a list of things they see during the weekend, or on their way to school, that connected to the topic of your course, what do you think they might come up with? Would each student have the same list? Might this be a good way to elicit class discussion and hear all student voices?

Additional ideas and handout templates can be found at https://cassidyinview.wordpress .com/in-class-activities/bring-the-outside-world-intoyour-class-and-vice-versa/

\section{Directions for Future Exploration}

As educational developers who conducted the daylong professional development workshops prior to the more traditional conference sessions, we have strong convictions about the unique value of these experiences, and these convictions are re-inforced by very positive participant response as well as literature on 'place-based' learning, experiential learning, and the benefits of the outdoor setting for personal wellbeing and the development of a sense of community. As one participant notes, ... "I wish the whole Conference was like this." We have attempted to root our observations and resulting convictions further in the literature as well as the observations of others. While we will pursue our empirical experiences by organizing additional sessions of this kind, it is also important to 'drill down' further with regard to the actual impacts of these workshops in an attempt to observe and measure intended and unintended learning outcomes on the practicing instructor in higher education.

What is more, the emerging Scholarship of Teaching and Learning (SoTL) practices in higher education require us to make every attempt to give scholarly attention to our pedagogical practices and to disseminate findings broadly in the higher education community. Future sessions of this nature may involve replication studies, pre- and post-session participant surveys, post-session follow up surveys and interviews after six months, and identification of transfer of professional development learning to actual pedagogical practice in the undergraduate or graduate studies setting. Similar to many of our practices in academic development, the period of intuitive and participant satisfaction-based motivation must give way to a more scholarly approach... without creating a negative climate of experimentation which overrides the fabulous individual and community 'joie de vivre' as participants 'paddle their own canoe'.

\section{References}

Ardoin, N. M., Schuh, J. S., \& Gould, R. K. (2012). Exploring the dimensions of place: a confirmatory factor analysis of data from three ecoregional sites. Environmental Education Research, 18, 583-607. http://dx.doi.org/10.1080/13504622.2011. 640930

Baldwin, L., Black, T., Cooke, L., Crawford, I., Naqvi, K., Ratsoy, G., Templeton, E., \& Waldichuk, T. (2013). Affective teaching: The place of place in interdisciplinary teaching. Transformative Dialogues: Teaching and Learning Journal, 6(3), 1-20. http://www.kpu.ca/sites/default/files/downlo ads/TD.6.3.9_Baldwin_etal_Affective_Teac hing.pdf 
Barr, R. B., \& Tagg, J. (1995). From teaching to learning: A new paradigm for undergraduate education. Change, 27(6), 13-25. http://www.jstor.org/stable/40165284

Brookfield, S. D. (2000). Transformative learning as ideology critique. In J. Mezirow \& Associates (Eds.), Learning as transformation: Critical perspectives on a theory in progress (pp. 125150). San Francisco, CA: Jossey-Bass.

Cranton, P. (1994). Understanding transformative learning. In Understanding and promoting transformative learning: A guide for educators of adults (pp. 22-42). San Francisco, CA: Jossey-Bass.

Godbey, G. (2009). Outdoor recreation, health, and wellness. Understanding and enhancing the relationship. Prepared for the Outdoor Resources Review Group Resources for the Future Background Study. Occasional Paper. May, 2009.

Gruenewald, D. A. (2003). The best of both worlds: A critical pedagogy of place. Educational Researcher, 32(4), 3-12. http://dx.doi.org/10. 3102/0013189X032004003

Kaplan, S. (1977). Tranquility and challenge in the natural environment. USDA Forest Service Tech Rep NE-30, 181-185.

Kaplan, S. (1995). The restorative benefits of nature: Toward an integrative framework. Journal of Environmental Psychology, 15, 169-182. http://dx.doi.org/10.1016/0272-4944(95) 90001-2

Kolb, D. A. (1984). Experiential learning: experience as the source of learning and development. Englewood Cliffs, NJ: Prentice-Hall.

Louv, R. (2012) The nature principle: Reconnecting with life in a virtual age. Chapel Hill, NC: Algonquin.
Lupien, S. J., Fiocco, A., Wan, N., Maheu, F., Lord, C., Schramek, T., \& Tu, M. T. (2005). Stress hormones and human memory function across the lifespan. Psychoneuroendocrinology, 30, 225-242. http://dx.doi.org/10.1016/ j.psyneuen.2004.08.003

Marcora, S., Staiano, W., \& Manning, V. (2009). Mental fatigue impairs physical performance in humans. Journal of Applied Physiology, 106, 857-864. http://dx.doi.org/10.1152/jappl physiol.91324.2008

Matsuoka, R. (2010). Student performance and high school landscapes: Examining the links. Landscape Urban Planning, 97, 273-282. http://dx.doi.org/10.1016/j.landurbplan.201 0.06 .011

Nesbit, S., \& Mayer, A. (2010). Shifting Attitudes: The Influence of Field Trip Experiences on Student Beliefs. Transformative Dialogues, 4(2), 1-22. http://www.kpu.ca/sites/default/ files/Teaching and Learning/TD.4.2.7_ Nesbit\%26Mayer_Shifting_Attidudes.pdf

Nisbet, E. K., \& Zelenski, J. M. (2011). Underestimating nearby nature: Affective forecasting errors obscure the happy path to sustainability. Psychological Science, 22, 1101 1106. http://dx.doi.org/10.1177/09567976 11418527

Revell, S., Duncan, E., \& Cooper, M. (2014). Helpful aspects of outdoor therapy experiences: An online preliminary investigation. Counselling and Psychotherapy Research, 14, 281-287. http://dx.doi.org/10.1080/14733145.2013. 818159

Selhub, E. M., \& Logan, A. C. (2012). Your brain on nature: The science of nature's influence on your health, happiness and vitality. Mississauga, ON: Wiley. 
Shin, W. S., Shin, C. S., Yeoun, P. S., \& Kim, J. J. (2011). The influence of interaction with forest on cognitive function. Scandinavian Journal of Forest Research 26, 595-598. http://dx.doi.org/10.1080/02827581.2011. 585996

Taylor, A., \& Kuo, F. (2009). Children with attention deficits concentrate better after walk in the park. Journal of Attention Disorders, 12, 402409. http://dx.doi.org/10.1177/1087054708 323000

Walter, P. (2011). Dead wolves, dead birds and dead trees: Catalysts for transformative learning in the making of scientist-environmentalists. Adult Education Quarterly, 63, 24-42. http://dx.doi.org/10.1177/0741713611426 348

Wattchow, B., \& Brown, M. (2011). A pedagogy of place: Outdoor education for a changing world. Clayton, VIC: Monash University Press.

Weinstein, N., Przybylski, A. K., \& Ryan, R. M. (2009). Can nature make us more caring? Effects of immersion in nature on intrinsic aspirations and generosity. Personality and Social Psychology Bulletin, 35, 1315-1329. http://dx.doi.org/10.1177/0146167 209341649

Wright, W. A., Monette, M. J., \& Hamilton, B. (2010). Paddle your own canoe: Metaphors for teaching between the tides. Collected Essays on Learning and Teaching, 3, 75-82. http://celt.uwindsor.ca/ojs/leddy/index.php/ CELT/index

Wright, W. A., Cassidy, A., \& Monette, M. J. (2013). Paddling through time: Learning for life in the coastal zone. Newsletter of the Society for Teaching and Learning in Higher Education (STLHE), 62 (Fall 2013), p.1-2.

\section{Acknowledgements}

We thank the three anonymous reviewers, whose comments helped us to improve this paper. We are grateful to the editors and organizers of CELT for their hard work on this publication.

\section{Biographies}

Alice L.E.V. Cassidy, Ph.D. is an Educational Developer, facilitator and science educator currently organizing first year courses in the Faculties of Science and Land and Food Systems (LFS) at the University of British Columbia. Having conducted field work for three degrees and as a wildlife consultant, she very much enjoys and has years of experience connecting students and teachers to the value of natural world connections to teaching and learning.

W. Alan Wright is Vice-Provost, Teaching and Learning, at the University of Windsor where he oversees the work of the Centre for Teaching and Learning and the Office of Open Learning. Dr. Wright has been a member of the STLHE for many years, and was one of the founding editors of the Green Guide publication series. He was the 2013 recipient of the Christopher Knapper Lifetime Achievement Award.

William B. Strean, Ph.D. is Professor, 3M National Teaching Fellow, and Education Director for the Integrative Health Institute at the University of Alberta. He incorporates nature, mindfulness, and somatics into his teaching and scholarship.

Gavan P.L. Watson is the Associate Director, eLearning at Western University's Teaching Support Centre. With a $\mathrm{PhD}$ in environmental education, Gavan has a professional background in educational development and has published widely on topics such as: the role of technology in non-formal environmental learning; teaching critical reflection to graduate students; and using social media in the university classroom. 